\title{
A Conceptual Overview of Attaining, Maintaining, and Regaining Shared Leadership in High Performing Teams
}

\author{
Nicholas P. de Cruz, MSc \\ Doctoral Researcher \\ School of Sport, Exercise and Rehabilitation Sciences \\ University of Birmingham
}

\begin{abstract}
With team-based structures replacing traditional hierarchical systems, the purpose of this paper was to explore the concept of shared leadership and its impact on improving team performance. The five underlying mechanisms that form the components which drive shared leadership, namely (1) trust, (2) empowerment, (3) age and maturity, (4) fair reward, and (5) dispositions and beliefs, provide readers with a practical understanding of how to attain, maintain, and regain shared leadership for the performance of teams in organisations today. In addition, a focus on shared leadership in other team contexts, such as sport, unconventional and multicultural environments is also discussed to aid the progression of shared leadership research and broaden its application beyond traditional business and managerial contexts.
\end{abstract}

Keywords: leadership, shared leadership, team performance, mechanisms

\section{Introduction}

Since the global financial crisis, the speed of response to environmental pressures to perform has become a dominant reality in organisations today. Coupled with the fast-changing environment, globalisation, and increasingly complex work tasks (Day, Gronn, \& Salas, 2006), it has become apparent that leadership has to be evenly distributed across the organisation to facilitate a faster response to cope with these demands (Pearce, Manz, \& Sims, 2009). According to O'Toole, Galbraith, and Lawler (2002), the skills and abilities to effectively lead organisations today has become increasingly difficult for any one individual to possess. Furthermore, as success is dependent on skilled professionals navigating through a web of complex and ambiguous environments, it is unlikely that a vertical or top-down approach by a single leader will be effective to achieve an organisation's goals (Pearce et al., 2009). Past research on leadership focused on singular, formal leaders, and their influence within organisations (Bass \& Bass, 2008). However, leadership is now viewed from a broader perspective, where a single formal leader only plays a part within the organisation (Day \& Harrison, 2007). Thus, the perception of leadership has shifted from the individual, "heroic" leader, to the importance of 
"we" in the leadership process (Yammarino, Salas, Serban, Shirreffs, \& Shuffler, 2012). In support, as leadership is inherently a social process and is influenced by other people (Pearce et al., 2009), the responsibility of leadership should be reliant on each member's expertise in order to address the task at hand (Friedrich, Vessey, Schuelke, Ruark, \& Mumford, 2009). As such, the team itself becomes an important source of leadership to effectively achieve the best performance for the organisation (Gronn, 2002).

Since leadership does not exist in a vacuum as the social environment of organisations is intense, dynamic, multifaceted, ambiguous, information-rich, and dependent on communication, team composition and types differ and pose various leadership challenges from context to context (Day et al., 2006). Also, as indicated by Pearce (2007), with thee progression into a knowledge era (work that requires the intellectual capital of skilled professionals), a commandand-control approach to leadership, that treats workers as interchangeable drones, is no longer suitable today. With the increasingly educated workforce, employees want to make a more meaningful contribution and not simply collect a pay cheque, which can be achieved through team-based leadership (Pearce \& Manz, 2005). A common theme in the new-genre leadership theories is an orientation toward development and change, rather than simply maintaining the status quo, where leadership can emerge from lower organisational levels (Uhl-Bien, Marion, \& McKelvery, 2007; Wang, Waldman, \& Zhang, 2014). Given that leadership is often distributed within a team, there is a need to focus on the broad array of processes that exist within teams, rather than just its formal leaders (Day et al., 2006). In this sense, leadership is not determined by positions of authority, but by individuals' knowledge and ability to influence peers, based on the situational needs of the team. As explained by Pearce and colleagues (2009), it is possible for individuals, who are not formally appointed as leaders, to rise to the occasion and exhibit leadership to cope with the demands of the moment, and then step back when appropriate to allow others to lead.

\section{Purpose of Article}

With team-based structures replacing traditional hierarchical systems, this concept of shared leadership has become increasingly important for organisations, practitioners and researchers alike, in the pursuit of higher performance (Avolio, Walumbwa, \& Weber, 2009). As such, the purpose of this paper was to explore the concept of shared leadership and its impact on improving team performance. To provide a holistic understanding of shared leadership, the direction of this review was guided by:

(1) A brief discussion on the essence of shared leadership.

(2) Highlight the link between shared leadership, performance, and its implications for organisations.

(3) Explore the underlying mechanisms of shared leadership that facilitate its promotion in relation to attaining, maintaining, and regaining shared leadership.

(4) Illustrate the current trend and alternative perspectives of shared leadership and its future direction for theory and practice. 


\section{Nature of Shared Leadership}

\section{Definition}

According to Avolio and colleagues (2009), the most widely cited definition of shared leadership illustrates "a dynamic, interactive influence process among individuals in groups for which the objective is to lead one another to the achievement of group or organisational goals or both. This influence process often involves peer, or lateral, influence and at other times involves upward or downward hierarchical influence" (Pearce \& Conger, 2003, p. 1). This implies that the structure of shared leadership does not involve distributing work responsibilities to all group members but rather engages subsets of group members to satisfy specific leadership functions as and when they are needed (Drescher, Korsgaard, Welpe, Picot, \& Wigand, 2014). As such, leadership behaviours vary based on the skills and resources of group members in relation to the task at hand. It is important to note that shared leadership differs from teamwork, where the former emphasises the distributed influence and responsibility among team members (Carson, Tesluk, \& Marrone, 2007), while the latter relates to a set of cooperatively inclined cognitions, attitudes, and actions which convert team member inputs to team outputs (Hollenbeck, Beersma, \& Schouten, 2012). In comparison to traditional forms of leadership, shared leadership involves broadly sharing power and influence among team members instead of centralising it in the hands of a dominant single "superior" individual (Pearce et al., 2009).

\section{Social and Dynamic}

It is still possible for shared leadership to work in conjunction with traditional, hierarchical leadership so as to give an organisation a more flexible, dynamic, robust, and responsive leadership platform (Pearce et al., 2009). In addition, shared leadership can comprise of other leadership behaviours such as transformational, transactive, participative, empowering, and aversive behaviours (Pearce \& Conger, 2003). In terms of the actual work that is performed, research has recognised that shared leadership is context specific, and therefore, what is being shared can influence team effectiveness (Wang et al., 2014). Accordingly, Pearce and Manz (2005) identified five factors, namely (1) level of urgency, (2) importance of employee commitment, (3) need for creativity and innovation, (4) level of interdependence, and (5) the degree of task complexity, that determine the appropriateness of shared leadership in an organisation. This demonstrates that shared leadership is a dynamic phenomenon as the sharing of leadership can change over time in any number of ways (Drescher et al., 2014). Day, Gronn, and Salas (2004) further explains that this ongoing nature of shared leadership develops and varies throughout a team's lifespan based on the inputs, processes, and outcomes of the team.

\section{Shared Leadership and Team Performance}

\section{Benefits}

As discussed above, shared leadership brings about the simultaneous, ongoing, mutual influence process within a team, which involves the emergence of official and unofficial leaders, and thus can be considered a case of fully developed empowerment among team members (Pearce \& Manz, 2005). Through empowering and promoting knowledge exchange, individuals' 
motivation to take responsibility can be enhanced, which consequently contributes to team cohesion, team consensus, and satisfaction (Bergman, Rentsch, Small, Davenport, \& Bergman, 2012). As individual strengths can be utilised throughout this process, organisations can benefit from the broad range of perspectives which inform decision making, by empowering team members to select the task they are best suited for and are most motivated to accomplish, thus reducing the burden on any single leader (Bligh, Pearce, \& Kohles, 2006; Miles \& Watkins, 2007; Pearce, 2007). Moreover, through increased information-processing and learning in shared leadership, team effectiveness can be enhanced from the increase in knowledge, abilities, and skills (Day et al., 2004). Indeed, as socialisation is enhanced among team members, the development of a collective vision of the organisation's strategy becomes a common mental model (Ensley, Pearson, \& Pearce, 2003). This gives organisations a competitive advantage as commitment increases in the personal and organisational resources to cope with complex tasks through reciprocity and information sharing (Carson et al., 2007).

\section{Evidence}

Research suggests that in self-managing project teams and decision-making teams, shared leadership exists and was found to be an important predictor of team outcomes (Bergman et al., 2012). In support, Pearce and Sims (2002) found that shared leadership increased team effectiveness among 71 change management teams based on the perceptions of team managers, team members, and customers. In a related study of 28 virtual project teams by Pearce, Yoo, and Alavi (2004), shared leadership was found to be more strongly related to members' commitment and confidence in the team's decision making in comparison to vertical leadership. This suggests that when team members were involved in the leadership of the team, they understood and accepted the rationale of decisions, and were therefore committed to its implementation. From an organisational level, where shared leadership was compared to vertical leadership among 66 new venture top management teams, performance was measured in terms of revenue growth and employee growth in a study by Ensley, Hmieleski, \& Pearce (2006) and found that both types of leadership were important for organisation performance. However, the influence of shared leadership was over and above what was predicted by the more traditional vertical leadership.

\section{Implications for Organisations}

It has become increasingly clear that there is more to gain by inculcating shared leadership into organisational structures. With the increased processing abilities of teams, there can be more leaders to address the team's developmental and functioning needs, such as the motivational, social, and cognitive processes that consequently influence a team's performance (Solansky, 2008). Furthermore, with shared leadership, there can be more opportunities for group members to engage in essential and much sought-after trust building interactions that are necessary for functional and successful groups (De Jong \& Dirks, 2012). That is not to say that vertical or more traditional forms of leadership should be disregarded for better team performance. It is possible that through vertical leadership, team leaders can demonstrate desirable leadership behaviours which can be adopted by team members, suggesting that vertical leaders can act as role models for the team (Pearce \& Manz, 2005; Pearce \& Sims, 2002). However, in sum, the influence of shared leadership in most settings has exceeded that of 
hierarchical leadership in predicting team and organisational outcomes to positively impact team performance (Hoch, Pearce, \& Welzel, 2010).

\section{Mechanisms of Shared Leadership}

When forming and developing shared leadership, a review of the literature showed that shared leadership is examined as a social construct, where meaning is created through a dialogue within groups of people in a specific context. As such, it would seem reductionistic to simply pigeonhole the underlying mechanisms of shared leadership into isolated categories like attaining, maintaining, and regaining as it would fail to capture the complex dynamics of shared leadership. To better illustrate the interaction and interdependence of the antecedents, facilitators, and mediators which influence shared leadership, the constructs which emerged from the literature will now be discussed in relation to attaining, maintaining, and regaining shared leadership. This is intended to provide readers with a holistic perspective of shared leadership, and the flexibility to interpret and apply the information presented below according to their situational needs.

\section{Trust}

Trust is critical to cooperation and performance within groups in addition to its strong link to shared leadership (Bergman et al., 2012; De Jong \& Dirks, 2012). Through frequent and meaningful ongoing interaction, team members become comfortable and open in sharing their individual experiences and contributions, where different opinions are valued over conformity, allowing ideas and assumptions to be challenged without fear or risk of judgement (Holton, 2001). This can facilitate an environment of mutual respect and understanding of the professional abilities among team members to be both an effective leader and follower. Furthermore, organisations can encourage shared interests and commonly shared values within teams to help establish and promote trust among team members (Quinn, Anderson, \& Finkelstein, 1996). Through the process of influencing and being influenced by one another, team members engage in positive social exchanges which builds trust and in turn, benefits team performance (Aime, Humphrey, DeRue, \& Paul, 2013; Drescher et al., 2014).

\section{Empowerment}

As leadership practices have evolved and reduced the dependence on traditional leader authority figures, Manz, Pearce, and Sims (2009) found empowerment to be a crucial factor within teams. Endorsing self-leadership is one way to promote feelings of empowerment through increasing employees' perceptions of meaningfulness, purpose, self-determination, and competence (Lee \& Koh, 2001). More specifically, organisations can encourage employees to establish strategies to achieve these psychological states which facilitate empowerment such as personal performance standards, self-evaluation, and goal setting (Manz \& Neck, 2004). Given that leadership requirements change with the progression of the team, higher authority figures (i.e., external or team leaders) need to adapt their behaviours to continuously guide and develop this independence, from that of a mentor, to a coach and finally, a facilitator (Kozlowski, Watola, Jensen, Kim, \& Botero, 2009). Leaders should note that although involvement in the decisionmaking process can promote feelings of empowerment, if employees feel that their input has 
little or no influence on work outcomes, this process may be perceived as transparently manipulative and result in lower levels of empowerment (Mielonen, 2011).

\section{Age and Maturity}

In relation to both the individual and the team itself, variations in age and maturity can produce a broad range of knowledge, skills and abilities which impact the quality of decision making and thus performance in teams (Hoch et al., 2010). As team members require time to develop an understanding of each other's skills and knowledge, more mature teams tend to have a greater ability to adopt shared leadership behaviours, in comparison to younger and less mature teams (Small \& Rentsch, 2010). It would seem that organisations would do well to ensure existing teams have continuity and allow for progression as a group, to facilitate effective team development. To address the chronological age of team members, Cox, Pearce, and Perry (2003) explained that heterogeneous teams may be less likely to engage in shared leadership, while the opposite effect was observed in homogeneous teams. Thus, organisations are recommended to focus on age similarity or managing age variation when forming teams especially when shared leadership is the objective (Hoch et al., 2010).

\section{Fair Rewards}

Apart from financial rewards, such as salary increase and bonuses, an important motivator that organisations should consider in order to promote and sustain shared leadership is appreciation, which can stem from either the leader or team members (Grille, Schulte, \& Kauffeld, 2015). As the nature of shared leadership requires voluntary actions from team members, personal contributions by team members should be rewarded to encourage their participation in shared leadership (Carson et al., 2007; Hoch \& Dulebohn, 2013). This can be achieved through providing career options and job security which can give team members the feeling of fair reward, and may be important in initiating and stimulating team members' participation and maintaining their efforts in shared leadership (Grille et al., 2015). Self-reward (i.e., reward that is concrete and of value to the individual) can also be used to energise the invested effort and provide sufficient leverage for future action as it is a way of congratulating oneself when a goal is accomplished (Manz \& Neck, 2004; Mielonen, 2011).

\section{Dispositions and Beliefs}

According the Drath and colleagues (2008), the major determinants and justification for shared leadership and its associated actions depend on the leadership beliefs of the organisation as a collective whole, and not just the behaviour of individuals. Therefore, to enforce an effective shared leadership strategy, it is important to consider the dispositions and beliefs of everyone in the organisation, not just the people in positions of authority (Mielonen, 2011). For example, by defining the team's mission, their purpose, goals, and tactical plans can be aligned with the broader organisation's expectations, strategies, and values to supplement shared leadership. In addition, it is critical that the dispositional composition of the team, in terms of members' collectivistic orientations, need to reflect a more willing disposition to engage in shared leadership even without personal knowledge of each other, especially if they are required to perform tasks in a new project (Pearce, Hoch, Jeppesen, \& Wegge, 2010; Small \& Rentsch, 
2010). If organisations can establish a climate which encourages and supports shared leadership, team members may in turn feel recognised and supported within their teams, and will therefore be more willing to share responsibility and attain the appropriate dispositions and beliefs to achieve collective goals (Carson et al., 2007).

\section{Alternative Perspectives of Shared Leadership}

According to Chelladurai (2012), high-quality leadership has been considered as a critical factor in the effective performance of governments, political movements, educational institutions, business enterprises, and sports teams. To represent a broad overview of this phenomenon in relation to shared leadership, more recent studies which go beyond the traditional business and managerial contexts will now be discussed to highlight areas which require further investigation.

\section{Athlete Leaders in Sport Teams}

Given that the structure of a sports team is similar to that of a business team, where both teams strive for visible performance outcomes and utilise formally appointed leaders, Fransen, Vanbeselaere, Cuyper, Broek, and Boen (2014) found that shared leadership was also associated with higher performance due to increased levels of team confidence and identification of common goals. However, the majority of research on leadership in sport settings has focused on the coach even though the presence of athlete leaders has been linked to higher performance, due to greater athletes' satisfaction and confidence, the team's cohesion and performance (Crozier, Loughead, \& Munroe-Chandler, 2013; Fransen et al., 2015). As shared leadership in sports has been associated with positive outcomes for both team members and leaders (Cotterill, 2013), it is important for coaches to acknowledge that team members (i.e., informal leaders) can take up leadership roles, thus strengthening athlete leadership and has the potential to create more optimal team functioning (Bucci, Bloom, Loughead, \& Caron, 2012; Price \& Weiss, 2011).

\section{Unconventional Environments}

Although shared leadership has been established as a dynamic concept (e.g., Pearce et al., 2009), little research has been conducted on shared leadership in unconventional environments such as extreme, unpredictable or dangerous situations (Campbell, Hannah, \& Matthews, 2010). It has been found that in the military, teams have often turned to shared leadership to achieve high performance through emergent leadership and mutual influence (Ramthun \& Matkin, 2014). In dangerous situations, team members may be willing to make sacrifices for the team as they identify with the team's purpose and mission, which enhances team members' potential and capabilities (Yammarino, Mumford, Connelly, \& Dionne, 2010). Yammarino and colleagues (2010) explain that it would be impractical to be dependent on only vertical leadership styles and in support, studies have found that team members can effectively negotiate time-sensitive and complex tasks in volatile and dangerous contexts by utilising shared leadership (Cox et al., 2003; Pearce \& Sims, 2002). Similarly, firefighting teams, police officers, and aircrew, who work in dangerous environments and face potentially life-threatening situations can achieve similar outcomes with shared leadership, but this warrants further investigation (Baran \& Scott, 2010; Hannah, Campbell, \& Matthews, 2010). 


\section{Intercultural Competence}

With globalisation in organisations today (Day et al., 2006), there has been an increasing urgency for individuals and teams to work effectively within these cultural differences (Spitzberg \& Changnon, 2009). This diversity may cause interpersonal barriers which inhibit shared leadership as it can limit or prevent team cohesion and disrupt the lateral influence among team members (Cox et al., 2003). However, Adler (2002) disagrees and postulates that cultural diversity is an asset to multicultural teams, especially if leaders can see past these differences, in the case of highly interculturally competent individuals. This requires appropriate and effective management when interacting with people by negotiating cultural beliefs and values for effective communication (Spitzberg \& Changnon, 2009). In so doing, individuals with high intercultural competence can transcend cultural differences in teams by overcoming the social and relational challenges which inhibit shared leadership (Ramthun \& Matkin, 2013). However, as experience is necessary to operate in these culturally diverse environments to avoid miscommunication, misunderstanding, and misinterpretation, studies should explore specific environments which reflect diverse cultures (Chin \& Sanchez-Hucles, 2007).

\section{Limitations and Future Directions}

Despite the social and dynamic nature of shared leadership, majority of research has been limited to studies conducted in North America and therefore the effects of shared leadership should be further explored in other cultural contexts (Pearce, 2008). To better understand the structural underpinnings of shared leadership there is a need to examine the nuances of how shared leadership is distributed over global boundaries and its impact on team performance (Nordback \& Espinosa, 2015). This can be facilitated with longitudinal designs in field settings, rather than experimental settings with student samples which may not reflect the unpredictability of "reality" where shared leadership is applied and practiced (Carson et al., 2007; Hoch et al., 2010). However, despite the emphasis of past research to utilise longitudinal designs in order to understand how shared leadership develops over time, the feasibility of such methods in this knowledge era are limited as organisations appear to be increasingly concerned about maintaining confidentiality of their intellectual property so as to remain competitive. It may be more prudent to use qualitative methods, supplemented by past quantitative studies, to focus on the lived experiences of team members and gain a more in-depth appreciation of shared leadership as it occurs (Smith \& Caddick, 2012), especially since shared leadership is an inherently social activity (Drescher et al., 2014). One of the criticisms of research on shared leadership involves the lack of consensus on its definition (Carson et al., 2007). As shared leadership is an ongoing and fluid process, it requires continuous re-evaluation and scrutiny (Scott \& Caress, 2005). Therefore, a concrete definition of shared leadership may not be desirable as it may fail to represent the flexible and responsive nature in the ever-changing environment of organisations. For a more holistic conceptualisation of shared leadership, Bergman and colleagues (2012) recommend that future research should examine shared leadership beyond its impact on performance, as organisations can capitalise on the many other benefits a shared leadership approach has to offer, such as a deterring executive corruption (Pearce, Manz, \& Sims, 2008) and improving teamwork among corporate boards (Conger \& 
Lawler, 2009). However, organisations need to be aware that there may be a danger of biasness in the selection of team members as shared leadership endorses homogeneity within teams, and thus may exclude individuals who may possess the knowledge, skills and abilities to improve team performance but are overlooked because they deviate from the norm. Notwithstanding these theoretical underpinnings of shared leadership, research has primarily focused on its antecedents and still lacks empirical evidence to close the gap between theory and practice (Hoch, 2013; Small \& Rentsch, 2010).

\section{Conclusion}

With the globalisation of organisations in this knowledge era, teams have become central to organisational success, where notions of a "heroic" leader may no longer be effective to achieve organisations' goals, due to the dynamic and fast-paced environment today. These demands suggest that organisations cannot wait for leadership decisions to be pushed up to the top for action. As such, leadership has to be more evenly shared across organisations to ensure faster response times to cope with environmental demands, making the need for shared leadership critical to achieve high performance. By focusing on the leadership processes within teams, rather than the leader of a team, this review has provided a holistic understanding of shared leadership in high performing teams to add to the growing literature of this concept. In doing so, the five underlying mechanisms that form the components which drive shared leadership, namely (1) trust, (2) empowerment, (3) age and maturity, (4) fair reward, and (5) dispositions and beliefs, provide readers with a practical understanding of how to attain, maintain, and regain shared leadership for the performance of teams in organisations today. A focus on shared leadership in other team contexts, such as sport, unconventional and multicultural environments is also important for the progression of shared leadership research as it may illuminate unforeseen factors which may potentially broaden the application of shared leadership beyond traditional business and managerial contexts. With the information above, researchers and practitioners are advised to engage in honest critical reflection for the advancement of shared leadership practice that transcends global boundaries.

\section{Conflict of Interest}

The author declares no conflict of interest.

\section{References}

Adler, N. (2002). International Dimensions of Organizational Behaviour. Cincinnati, OH: South-Western.

Aime, F., Humphrey, S., DeRue, D., \& Paul, J. (2013). The riddle of heterarchy: Power transitions in cross-functional teams. Academy of Management Journal, 57(2), 327 352.

Avolio, B., Walumbwa, F., \& Weber, T. (2009). Leadership: Current theories, research, and future directions. Annual Review of Psychology, 60(1), 421-449. 
Baran, B., \& Scott, C. (2010). Organizing ambiguity: A grounded theory of leadership and sensemaking within dangerous contexts. Military Psychology, 22(1), 42-69.

Bass, B. M., \& Bass, R. (2008). The Bass Handbook of Leadership: Theory, Research and Managerial Implication.. New York, NY: Free Press.

Bergman, J. Z., Rentsch, J. R., Small, E. E., Davenport, S. W., \& Bergman, S. M. (2012). The shared leadership process in decision-making team. The Journal of Social Psychology, 152(1), 17-42.

Bligh, M. C., Pearce, C. L., \& Kohles, J. C. (2006). The importance of self and shared leadership in team based knowledge work: A meso-level model of leadership dynamics. Journal of Managerial Psychology, 21(4), 296-318.

Bucci, J., Bloom, G. A., Loughead, T. M., \& Caron, J. G. (2012). Ice hockey coaches' perceptions of athlete leadership. Journal of Applied Sport Psychology, 24(3), 243 259.

Campbell, D., Hannah, S., \& Matthews, M. (2010). Leadership in military and other dangerous contexts: Introduction to the special topic issue. Military Psychology, 22(1), $1-14$.

Carson, J. B., Tesluk, P. E., \& Marrone, J. A. (2007). Shared leadership in teams: An investigation of antecedent conditions and performance. Academy of Management Journal, 50(5), 1217-1234.

Chelladurai, P. (2012). Models and measurement of leadership in sport. In G. Tenenbaum, R. C. Eklund \& A. Kamata (Eds.), Measurement in Sport and Exercise Psychology (pp. 433-442). Champaign, IL: Human Kinetics.

Chin, J., \& Sanchez-Hucles, J. (2007). Diversity and leadership. American Psychologist, 62(6), 608-609.

Conger, J. A., \& Lawler, E. E. (2009). Sharing leadership on corporate boards: A critical requirement for teamwork at the top. Organizational Dynamics, 38(3), 183-191.

Cotterill, S. (2013). Team Psychology in Sports: Theory and Practice. Abingdon: Routledge.

Cox, J. F., Pearce, C. L., \& Perry, M. (2003). Toward a model of shared leadership and distributed influence in the innovation process: How shared leadership can enhance new product development team dynamics and effectiveness. In C. L. Pearce \& J. A. Conger (Eds.), Shared Leadership: Reframing the Hows and Whys of Leadership (pp. 48-68). Thousand Oaks, CA: Sage.

Crozier, A. J., Loughead, T. M., \& Munroe-Chandler, K. J. (2013). Examining the benefits of athlete leaders in sport. Journal of Sport Behaviour, 36(4), 346-364.

Day, D. V., Gronn, P., Salas, E. (2006). Leadership in team-based organisations: On the threshold of a new era. The Leadership Quarterly, 17(3), 211-216. 
Day, D. V., Gronn, P., Salas, E. (2004). Leadership capacity in teams. The Leadership Quarterly, 15(6), 857-880.

Day, D. V., \& Harrison, M. M. (2007). A multilevel, identity-based approach to leadership development. Human Resource Management Review, 17(4), 360-373.

De Jong, B. A., \& Dirks, K. T. (2012). Beyond shared perceptions of trust and monitoring in teams: Implications of asymmetry and dissensus. Journal of Applied Psychology, 97(2), 391-406.

Drath, W. H., McCauley, C. D., Palus, C. J., Van Velsor, E., O’Connor, P. M., \& McGuire, J. B. (2008). Direction, alignment, commitment: Toward a more integrative ontology of leadership. The Leadership Quarterly, 19(6), 635-653.

Drescher, M. A., Korsgaard, M. A., Welpe, I. M., Picot, A., \& Wigand, R. T. (2014). The dynamics of shared leadership: Building trust and enhancing performance. Journal of Applied Psychology, 99(5), 771-783.

Ensley, M. D., Hmieleski, K. M., \& Pearce, C. L. (2006). The importance of vertical and shared leadership within new venture top management teams: Implications for theperformance of startups. The Leadership Quarterly, 17(3), 217-231.

Ensley, M. D., Pearson, A., \& Pearce, C. L. (2003). Top management team process, shared leadership, and new venture performance: A theoretical model and research agenda. Human Resource Management Review, 13(2), 329-346.

Fransen, K., Puyenbroeck, S. V., Loughead, T. M., Vanbeselaere, N., Cuyper, B. D., Broek, G. V., \& Boen, F. (2015). Who takes the lead? Social network analysis as a pioneering tool to investigate shared leadership within sports teams. Social Networks, $43,28-38$.

Fransen, K., Vanbeselaere, N., Cuyper, B. D., Broek, G. V., \& Boen, F. (2014). The myth of the team captain as principal leader: Extending the athlete leadership classification within sport teams. Journal of Sport Sciences, 32(14), 1389-1397.

Friedrich, T. L., Vessey, W. B., Schuelke, M. J., Ruark, G. A., \& Mumford, M. D. (2009). A framework for understanding collective leadership: The selective utilization of leader and team expertise within networks. The Leadership Quarterly, 20(6), 933-958.

Grille, A., Schulte, E., \& Kauffeld, S. (2015). Promoting shared leadership: A multilevel analysis investigating the role of prototypical team leader behaviour, psychological empowerment, and fair rewards. Journal of Leadership and Organisational Studies, 22(3), 324-339.

Gronn, P. (2002). Distributed leadership as a unit of analysis. The Leadership Quarterly, 13(4), $423-451$

Hannah, S., Campbell, D., \& Matthews, M. (2010). Advancing a research agenda for leadership in dangerous contexts. Military Psychology, 22(1), 157-189. 
Hoch, J. E. (2013). Shared leadership and innovation: The role of vertical leadership and employee integrity. Journal of Business and Psychology, 28(2), 159-174.

Hoch, J. E., \& Dulebohn, J. H. (2013). Shared leadership in enterprise resource planning and human resource management system implementation. Human Resource Management Review, 23(1), $114-125$.

Hoch, J. E., Pearce, C. L., \& Welzel, L. (2010). Is the most effective team leadership shared?: The impact of shared leadership, age diversity, and coordination on team performance. Journal of Personnel Psychology, 9(3), 105-116.

Hollenbeck, J. R., Beersma, B., \& Schouten, M. E. (2012). Beyond team types and taxonomies: A dimensional scaling conceptualization for team description. The Academy of Management Review, 37(1), 82-106.

Holton, J. A. (2001). Building trust and collaboration in a virtual team. Team Performance Management, 7(3), 36-48.

Kozlowski, S. W., Watola, D. J., Jensen, J. M., Kim, B. H., \& Botero, I. C. (2009). Developing adaptive teams: A theory of dynamic team leadership. In E. Salas, G.

F.Goodwin \& C. S. Burke (Eds.), Team Effectiveness in Complex Organizations:Crossdisciplinary Perspectives and Approaches (pp. 113-156). New York: NY:Psychology Press.

Lee, M., \& Koh, J. (2001). Is empowerment really a new concept. International Journal of Human Resource Management, 12(4), 684 - 695.

Manz, C. C., \& Neck, C. P. (2004). Mastering Self-Leadership: Empowering Yourselffor Personal Excellence. Upper Saddle River, NJ: Pearson Prentice-Hall.

Manz, C. C., Pearce, C. L., \& Sims, H. P. (2009). The ins and outs of leading teams: An overview. Organizational Dynamics, 83(3), 179 - 182.

Mielonen, J. (2011). Making sense of shared leadership: A case study of leadership processes and practices without formal leadership structure in the team context (Unpublished doctoral dissertation). Lappeenranta University of Technology, Finland.

Miles, S. A., \& Watkins, M. D. (2007). The leadership team: Complementary strengths or conflicting agendas? Harvard Business Review, 85(4), 90-98.

Nordback, E., \& Espinosa, A. (2015). Cognitive and behavioural leadership coordination: Linking shared leadership to high performance in global teams. System Sciences, 402411. doi: 10.1109/HICSS.2015.56

O'Toole, J., Galbraith, J., \& Lawler, E. E. (2002). When two (or more) heads are better than one: The promise and pitfalls of shared leadership. California Management Review, 44(4), 65-83. 
Pearce, C. L. (2008). Follow the leaders. Wall Street Journal-Eastern Edition,252, R8

Pearce, C. L. (2007). The future of leadership development: The importance of identity, multi-level approaches, self-leadership, physical fitness, shared leadership, networking, creativity, emotions, spirituality and on-boarding processes. Human Resource Management Review, 17(4), 355-359.

Pearce, C. L., \& Conger, J. A. (2003). Shared Leadership: Reframing the Hows and Whys of Leadership. Thousand Oaks, CA: Sage.

Pearce, C. L., Hoch, J. E., Jeppesen, H. J., \& Wegge, J. (2010). New forms of management: Shared and distributed leadership in organisations. Journal of Personnel Psychology, 9(4), 151-153.

Pearce, C. L., \& Manz, C. C. (2005). The new silver bullets of leadership: The importance of self- and shared leadership in knowledge work. Organisational Dynamics, 34(2), 130140.

Pearce, C. L., Manz, C. C., \& Sims, H. P. (2009). Where do we go from here?: Is shared leadership the key to team success. Organisational Dynamics, 38(3), 234-238.

Pearce, C. L., Manz, C. C., \& Sims, H. P. (2008). The roles of vertical and shared leadership in the enactment of executive corruption: Implications for research and practice. The Leadership Quarterly, 19(3), 353-359.

Pearce, C. L., \& Sims, H. P. (2002). Vertical versus shared leadership as predictors of the effectiveness of change management teams: An examination of aversive, directive, transactional, transformational, and empowering leader behaviours. Group Dynamics: Theory, Research, and Practice, 6(2), 172-197.

Pearce, C. L., Yoo, Y., \& Alavi, M. (2004). Leadership, social work, and virtual teams: The relative influence of vertical versus shared leadership in the nonprofit sector. In R. E. Riggio \& S. S. Orr (Eds.), Improving Leadership in Nonprofit Organisations (pp. 180203). San Francisco, CA: Jossey Bass.

Price, M. S., \& Weiss, M. R. (2011). Peer leadership in sport: Relationships among personal characteristics, leader behaviours, and team outcomes. Journal of Applied Sport Psychology, 23(1), 49-64.

Quinn, J. B., Anderson, P., \& Finkelstein, S. (1996). Managing professional intellect: Making the most of the best. Harvard Business Review, 74(2), 71-80.

Ramthun, A. J., \& Matkin, G. S. (2014). Leading dangerously: A case study of military teams and shared leadership in dangerous environments. Journal of Leadership and Organisational Studies, 21(3), 244-256.

Ramthun, A. J., \& Matkin, G. S. (2013). Multicultural shared leadership: A conceptual model of shared leadership in culturally diverse teams. Journal of Leadership and Organisational Studies, 19(3), 303-314. 
Scott, L., \& Caress, A. (2005). Shared governance and shared leadership: Meeting the challenges of implementation. Journal of Nursing Management, 13(1), 4-12.

Small, E. E., \& Rentsch, J. R. (2010). Shared leadership in teams: A matter of distribution. Journal of Personnel Psychology, 9(4), 203-211.

Smith, B., \& Caddick, N. (2012). Qualitative methods in sport: A concise overview for guiding social scientific sport research. Asia Pacific Journal of Sport and Social Science, 1(1), 60-73.

Solansky, S. T. (2008). Leadership style and team processes in self-managed teams. Journal of Leadership and Organisational Studies, 14(4), 332-341.

Spitzberg, B., \& Changnon, G. (2009). Conceptualizing intercultural competence. In D. Deardorff (Ed.), The Sage handbook of intercultural competence (pp. 2-52). Thousand Oaks, CA: Sage.

Uhl-Bien, M., Marion, R., \& McKelvery, B. (2007). Complexity leadership theory: Shifting leadership form the industrial age to the knowledge era. The Leadership Quarterly, 18(4), 298-318.

Wang, D., Waldman, D. A., \& Zhang, Z. (2014). A meta-analysis of shared leadership and team effectiveness. Journal of Applied Psychology, 99(2), 181-198.

Yammarino, F. J., Mumford, M., Connelly, M., \& Dionne, S. (2010). Leadership and team dynamics for dangerous military contexts. Military Psychology, 22(1), 15-41.

Yammarino, F. J., Salas, E., Serban, A., Shirreffs, K., \& Shuffler, M. L. (2012). Collectivistic leadership approaches: Putting the "we" in leadership science and practice. Industrial and Organisational Psychology, 5(4), 382-402.

\section{Author Biography}

Nicholas de Cruz (npd664@bham.ac.uk) is a doctoral researcher in the School of Sport, Exercise and Rehabilitation Sciences at the University of Birmingham. His research is centred around cultural sport psychology and elite sport in Singapore. 